\title{
Central growth hormone signaling is not required for the timing of puberty
}

\author{
Tabata M Bohlen ${ }^{1}$, Thais T Zampieri', Isadora C Furigo², Pryscila D S Teixeira², Edward O List ${ }^{3}$, John J Kopchick ${ }^{3}$, \\ Jose Donato Jr2 and Renata Frazao ${ }^{1}$
}

1Department of Anatomy, Institute of Biomedical Sciences, University of São Paulo, São Paulo, São Paulo, Brazil 2Department of Physiology and Biophysics, Institute of Biomedical Sciences, University of São Paulo, São Paulo, São Paulo, Brazil ${ }^{3}$ Edison Biotechnology Institute and Heritage College of Osteopathic Medicine, Ohio University, Athens, Ohio, USA

Correspondence should be addressed to R Frazao: rfrazao@usp.br

\begin{abstract}
Growth hormone (GH) is a key factor in the regulation of body growth, as well as a variety of other cellular and metabolic processes. Neurons expressing kisspeptin and leptin receptors (LepR) have been shown to modulate the hypothalamic-pituitarygonadal (HPG) axis and are considered GH responsive. The presence of functional GH receptors (GHR) in these neural populations suggests that $\mathrm{GH}$ may regulate the HPG axis via a central mechanism. However, there have been no studies evaluating whether or not $\mathrm{GH}$-induced intracellular signaling in the brain plays a role in the timing of puberty or mediates the ovulatory cycle. Toward the goal of understanding the influence of GH on the central nervous system as a mediator of reproductive functions, GHR ablation was induced in kisspeptin and LepR-expressing cells or in the entire brain. The results demonstrated that GH signaling in specific neural populations can potentially modulate the hypothalamic expression of genes related to the reproductive system or indirectly contribute to the progression of puberty. GH action in kisspeptin cells or in the entire brain was not required for sexual maturation. On the other hand, GHR ablation in LepR cells delayed puberty progression, reduced serum leptin levels, decreased body weight gain and compromised the ovulatory cycle in some individuals, while the lack of GH effects in the entire brain prompted shorter estrous cycles. These findings suggest that $\mathrm{GH}$ can modulate brain components of the HPG axis, although central GH signaling is not required for the timing of puberty.
\end{abstract}
Key Words
- reproduction
- estrous cycle
- kisspeptin
- leptin
- energy balance

\section{Introduction}

Puberty is a complex phenomenon modulated by genetic, epigenetic, environmental, nutritional and hormonal factors. Both the onset and proper development of sexual maturation depend on augmented sex steroid levels, and the ability of the HPG axis to respond to this increase. Puberty culminates with HPG axis maturation and the attainment of fertility (Lomniczi et al. 2013, Lehman et al. 2018). (c) 2019 Society for Endocrinology Published by Bioscientifica Ltd. Printed in Great Britain
Sex steroid receptors are widely distributed in several organs and tissues, including hypothalamic component of the HPG axis. Interestingly, the HPG and somatotropic axes are mutually regulated. Accordingly, increased sex steroid secretion, which occurs during puberty, inhibits catecholamine pathways, reducing hypothalamic somatostatin secretion and facilitating growth hormonereleasing hormone (GHRH) release (Devesa et al. 1992). 
Consequently, these alterations induce growth hormone (GH) secretion, stimulate insulin growth factor-1 (IGF-1) production and together promote longitudinal body growth (Devesa et al. 1992).

In addition to growth, adequate GH serum levels are also required for normal sexual maturation and ovulatory cycle maintenance (Eden 1979, Steyn et al. 2016). For example, in adult females the increase in both the amplitude and frequency of plasma GH pulses coincides with a progressive rise in the ovarian production of estradiol during the late follicular phase of the menstrual cycle (Steyn et al. 2016). GH deficiency or resistance has been shown to delay the onset of puberty, resulting in incomplete sexual maturation and infertility (Advis et al. 1981, Albanese \& Stanhope 1994, De Boer et al. 1997, Zhou et al. 1997, Smuel et al. 2015, Devesa et al. 2016). In fact, previous studies have shown that GH administration can accelerate puberty onset in normal individuals and restore the time of puberty and fertility in GH-deficient dwarf mice (Bartke 1964) or in previously infertile GH-deficient women (Giampietro et al. 2009). However, the molecular and cellular mechanisms by which GH regulates the reproductive system are not fully understood.

GH receptors (GHRs) belong to the type I cytokine receptor family and are widely distributed in several organs and tissues, including the CNS (Walsh et al. 1990, Burton et al. 1992, Furigo et al. 2017). Hypothalamic GH-responsive neurons have been identified and some of these neural populations are known to modulate the HPG axis. For example, kisspeptin neurons located at the anteroventral periventricular and rostral periventricular nuclei (AVPV/PeN) are GH responsive and are essential modulators of the estrogen-mediated positive-feedback mechanism (Lehman et al. 2018, Silveira et al. 2019). In addition, LepR-expressing neurons in the arcuate nucleus $(\mathrm{ARH})$ and ventral premammillary nucleus (PMv) are also GH responsive (Cady et al. 2017, Furigo et al. 2019, Silveira et al. 2019). Among the ARH neurochemical populations, both agouti-related peptide (AgRP) and proopiomelanocortin (POMC) neurons co-express LepR and are considered mediators of the energy balance status and HPG axis function (Manfredi-Lozano et al. 2016, Padilla et al. 2017). On the other hand, PMv neurons integrate sensory and circulating hormone signals, conveying metabolic cues to the reproductive system (Beltramino \& Taleisnik 1985, Donato et al. 2009, 2010, 2013, Donato \& Elias 2011, Leshan \& Pfaff 2014, Ross et al. 2018). Due to the fact that these neural populations express functional GHR, it is plausible that GH is involved in the regulation of the HPG axis, at the level of the hypothalamus. However, no studies to our knowledge have evaluated whether GH-induced intracellular signaling in the brain is involved in the time of puberty onset or ovulatory cycle mediation.

Toward the goal of attaining a better understanding about the role of GH action in these processes, GHR expression was ablated in specific neural populations, which included kisspeptin cells, LepR cells, as well as in the entire brain (nestin-expressing cells). The results from the present study represent an important initial step for determining whether GH therapy, for the treatment of GH disorders or other endocrine dysfunctions (Souza \& Collett-Solberg 2011), modulates the HPG axis via specific hypothalamic neuronal populations.

\section{Materials and methods}

\section{Animals}

For genetic GHR ablation, mice carrying loxP-flanked Ghr alleles (List et al. 2013, 2014) were bred either with Kiss1-Cre mice (strain C57BL/6-Tg(Kiss1-Cre)J2-4Cfe/J, The Jackson Laboratory), LepR-IRES-Cre mice

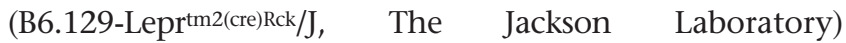
or Nestin-Cre mice (B6.Cg-Tg(Nes-cre)1Kln/J, The Jackson Laboratory). Heterozygous offspring were then crossed with homozygous Ghr-floxed mice, which then generated mice homozygous for Ghr-floxed alleles, expressing Kiss1-dependent (Kiss1-KO), LepR-dependent (LepR-KO) or nestin-dependent (Nestin-KO, here referred to as Brain-KO) Cre. Animals that did not express Cre were used as controls.

For histological experiments, Kiss1-Cre and Kiss1-KO mice were crossed with Cre-inducible GFP-reporter mice (Stock No: 004178, The Jackson Laboratory) and LepR-KO mice were crossed with Lox-Stop-Lox (LSL) Cre-inducible tdTomato-reporter mice (Stock No: 007909, The Jackson Laboratory). Kiss1-KO/GFP or LepR-Cre/tdTomato-KO heterozygous offspring were then crossed to homozygous Ghr-floxed mice generating homozygous KO mice carrying the reporter protein. Under these breeding conditions, kisspeptin and LepR expression could be visualized by GFP and tdTomato fluorescence, respectively. At 3 weeks of age, mice were weaned and genotyped via PCR with DNA extracted from tail clips (REDExtract-N-Amp ${ }^{\mathrm{TM}}$ Tissue PCR Kit, Sigma).

Kiss-KO mice and their respective controls were produced and studied in the animal care facility of the Department of Anatomy, Institute of Biomedical Sciences (ICB) at the University of São Paulo (USP). 
LepR-KO, brain-KO and their respective control mice were produced and studied in the animal care facility of the Department of Physiology and Biophysics (ICB/USP). The environmentally controlled rooms had a 12 -h on/12-h off light cycle (lights on at 06:00 h) and the temperature was maintained between 21 and $23^{\circ} \mathrm{C}$. All animal procedures were approved by the ICB Ethics Committee on the Use of Animals at USP and were performed according to the ethical guidelines adopted by the Brazilian College of Animal Experimentation.

\section{Identification of GH-induced phosphorylation of the signal transducer and activator of transcription 5 (pSTAT5)}

To identify GH-responsive cells, Kiss1-KO/GFP, LepR-Cre/tdTomato-KO and respective control mice received a single intraperitoneal injection of sterile saline $(n=3)$ or porcine pituitary GH, a selective agonist of GHR $(20 \mu \mathrm{g} / \mathrm{g}, n=3)$, purchased from Dr A F Parlow (National Hormone and Peptide Program, USA). After $90 \mathrm{~min}$, mice were deeply anesthetized and transcardially perfused with saline followed by perfusion with a $10 \%$ buffered formalin solution. The brains were collected, post-fixed in the same fixative for $1 \mathrm{~h}$ and cryoprotected in $0.1 \mathrm{M}$ phosphate buffer saline (PBS) containing 20\% sucrose, $\mathrm{pH}$ 7.4 , overnight at $4^{\circ} \mathrm{C}$. Brains were sliced into $30 \mu \mathrm{m}$ thick sections using a freezing microtome. Four series of tissue were collected, transferred to an antifreeze solution and stored at $-20^{\circ} \mathrm{C}$

Brain sections were rinsed with $0.02 \mathrm{M}$ potassium PBS, pH 7.4 (KPBS), followed by a pretreatment in an alkaline $(\mathrm{pH}>13)$ water solution containing $1 \%$ hydrogen peroxide and $1 \%$ sodium hydroxide for $20 \mathrm{~min}$. Sections were then incubated in $0.3 \%$ glycine and $0.03 \%$ lauryl sulfate, for $10 \mathrm{~min}$ each. The sections were blocked using 3\% normal donkey serum (Jackson Immunoresearch) for $1 \mathrm{~h}$, and incubated with anti-pSTAT5Tyr694 (\#9351; Cell Signaling Technology) diluted 1:1000 in KPBS containing $0.25 \%$ Triton $\mathrm{X}-100$ at $4^{\circ} \mathrm{C}$ for $40 \mathrm{~h}$. Next, the sections were washed with KPBS and incubated with anti-rabbit IgG conjugated to AlexaFluor ${ }^{488}$ or AlexaFluor ${ }^{594}$ diluted 1:500 (Jackson Immunoresearch) for $90 \mathrm{~min}$. Sections were mounted onto gelatin-coated slides with Fluoromount $G$ coverslips (Electron Microscopic Sciences, Hatfield, USA). Photomicrographs of the brain sections were acquired with a Zeiss Axiocam HRc camera coupled to a Zeiss Axioimager A1 microscope (Zeiss). Images were digitized using the Axiovision software (Zeiss).

\section{Serum dosages and tissue collection}

Leptin and GH levels were assessed in blood samples of 42-day-old female mice (collection time at 12:00-14:00 h). Before euthanasia, the nose-anus length was assessed to determine body growth. Serum concentrations of leptin (\#90030; Crystal Chem, Elk Grove Village, IL, USA) and GH (EZRMGH-45K; Millipore) were determined with commercially available ELISA kits, according to the instructions of the manufacturer. Leptin and GH ELISA kits have a detection limit of $0.2 \mathrm{ng} / \mathrm{mL}$ and $0.07 \mathrm{ng} / \mathrm{mL}$, respectively, and an intra- and inter-assay coefficient of variability $\leq 10 \%$. The hypothalamus and uterus were also collected for subsequent analyses.

\section{Relative gene expression}

Total RNA from the hypothalamus of 42-day-old mice and from ovaries of adult female mice (70-130 days of age) were extracted with TRIzol reagent according to the manufacturer's instructions (Thermo Fisher Scientific). Total RNA from uterine fat pad was extracted with GE Healthcare illustra ${ }^{\mathrm{TM}}$ Microspin G-50 Columns, according to the manufacturer's instructions (Thermo Fisher Scientific). RNA quantification was performed spectrophotometrically using an Epoch Microplate Spectrophotometer (BioTek, Winooski, VT, USA). The RNA samples were incubated in RNase-free DNase I (Roche Applied Science). Reverse transcription was performed using $2 \mu \mathrm{g}$ of total hypothalamic RNA, SuperScript II Reverse Transcriptase (Thermo Fisher Scientific) and random primers $\mathrm{p}(\mathrm{dN}) 6$ (Roche Applied Science). Realtime polymerase chain reaction (RT-PCR) was performed using a 7500 Real-Time PCR System (Thermo Fisher Scientific) and Power SYBR Green PCR Master Mix (Thermo Fisher Scientific). All samples were run in duplicates and negative controls were included at each qPCR run. Relative mRNA expression was quantified by calculating $2^{-\Delta \Delta C t}$. Data were normalized to the geometric average of housekeeping genes Actb, Gapdh, Ppia and reported as fold change, when compared to values obtained from the control group (set at 1.0). The primers for the following gene were used: $A c t b$ (forward: gctccggcatgtgcaaag; reverse: catcacaccctggtgccta), Gapdh (forward: gggtcccagcttaggttcat; reverse: tacggccaaatccgttcaca), Ppia (forward: cttcttgctggtcttgccattcc reverse: tatctgcactgccaagactgagt), Agrp (forward: ctttggcggaggtgctagat; reverse: aggac tcgtgcagccttacac), Cartpt (forward: cagtcacacagcttcccgat; reverse: cagatcgaagcgttgcaaga), Esr1 (forward: tggagattcaagtccccaaa; reverse: gcagatagggagctggttca), 
Esr2 (forward: ttgtaccetcgaagcgtgtga; reverse: gccaacctcctgatgcttcttt), Gal (forward: tgtcgctaaa tgatctgtggttgtc; reverse: tgcaaccetgtcagccactc), Gnrh1 (forward: gggttctgccatttgatccac; reverse: cccttga ctttcacatcc), Ghr (forward: atcaatccaagctggggac; reverse: acagctgaatagatcctgggg), Kiss1 (forward: gattcctttt cccaggcatt; reverse: ggcaaaagtgaagcctggat), Nos1 (forward: cggaccttgtagctcttcctc; reverse: ttcggctgtgctttgatgga), Npy (forward: cagatactactccectctgcg; reverse: gggctggatctcttgccata), Pomc (forward: tagatgtgtggagctggtgc; reverse: ccagcgagaggtcgagtttg) and Tac2 (forward: tgcatgtcacgtttctgtgg; reverse: ccgctccatctctctggaag).

\section{Sexual maturation and estrous cycle evaluation}

Sexual maturation was assessed by recording the age of vaginal opening and the first vaginal cornification in the vaginal lavage (first estrus) occurrence (Nelson et al. 1990, Bohlen et al. 2016). Estrous cycle length was assessed daily evaluating the vaginal lavage in control and adult female KO mice. Three consecutive estrous cycles were evaluated, and the average percentage of days in which cornified cells or leucocytes were detected in the vaginal smear were determined. Mice were monitored daily (from 21 days of age to approximately 130 days). Body weight was monitored weekly, as well as at each specific stage of sexual maturation (vaginal opening and first estrus). Total body fat and lean mass were further measured from adult control, LepR-KO and Brain-KO mice by timedomain nuclear magnetic resonance using the LF50 body composition mice analyzer (Bruker, Germany). Adult mice were killed, and the uterine and the fat pad masses were measured.

\section{Statistical analysis}

Statistical analyses were performed using GraphPad Prism software. The data were expressed as the mean \pm standard error of the mean (s.E.M.). The comparisons between Kiss1-KO and control groups were made using the unpaired two-tailed Student's t-test. The Mann-Whitney test was used to evaluate the puberty events. Two-way ANOVA and the Bonferroni post-test were employed for temporal body weight analyses. Data collected from LepR-KO and Brain-KO mice were compared to control using one-way ANOVA and the Dunnett's post-test or the Kruskal-Wallis test to evaluate puberty events. Results with a $P$ value $<0.05$ were considered to be statistically significant.

\section{Results}

\section{Mouse model validation}

To confirm GHR ablation in Kiss1-Cre specific expressing cells (here designated as kisspeptin cells), Kiss1-Cre/GFP (control) and Kiss1-KO/GFP mice received acute injections of saline or porcine $\mathrm{GH}$ and the pSTAT5 was assessed in brain sections. The immunoreactivity of pSTAT5 has been described as a marker for GH-responsive cells (Furigo et al. 2017, Silveira et al. 2019). As expected, there was virtually no pSTAT5 detected in samples from animals injected with saline (Fig. 1A). On the other hand, GH injection induced pSTAT5 in a subset of AVPV/PeN kisspeptin neurons in control mice $(11.2 \pm 1.3$ of $36.2 \pm 5.6$ cells, Fig. 1B). Kiss1-KO mice showed a striking reduction in the number of kisspeptin cells containing GH-induced pSTAT5 $(2.2 \pm 0.7$ of $26.0 \pm 2.7$ cells; $P=0.01$ vs control mice), although the surrounding cells in the AVPV/PeN area remained largely GH responsive (Fig. 1C). The non-GH-responsive phenotype of ARH kisspeptin cells (control: $1.0 \pm 0.2$ of $45.0 \pm 6.8$ cells, Kiss1-KO: $1.2 \pm 0.2$ of $51.0 \pm 7.5$ cells; Fig. $1 \mathrm{D}, \mathrm{E}$ and F) is consistent with a previous study (Silveira et al. 2019).

The pSTAT5 immunoreactivity was also evaluated in LepR-Cre/tdTomato (control) and LepR-KO/tdTomato mice injected with $\mathrm{GH}$. Most of the LepR-expressing neurons located in the ARH (Fig. 2A) and PMv (Fig. 2C) were found to be $\mathrm{GH}$ responsive in control mice, as previously shown (Cady et al. 2017, Furigo et al. 2019). In contrast, there was virtually no pSTAT5 in LepR-expressing cells from LepR-KO mice injected with GH (Fig. 2B and D). Furthermore, brain GHR ablation was evaluated by assessing hypothalamic Ghr mRNA expression. Brain-KO mice had significantly reduced hypothalamic Ghr mRNA expression levels $(0.2 \pm 0.0$ a.u. $)$, when compared to the control group $(1.0 \pm 0.1 ; P<0.0001)$. Since LepR and nestin are also expressed in peripheral tissues, Ghr mRNA levels were determined in the ovaries and perigonadal fat, but no significant differences were observed between the groups (Table 1). Together the results demonstrated that the neuron-specific genetic deletions were present and effective in all of the studied mouse models.

\section{Central GH influence on hypothalamic gene expression}

To determine whether GH-induced intracellular signaling modulates hypothalamic gene expression in specific hypothalamic cells or in the entire brain, the hypothalami of pubertal 40- to 42-day-old female mice, 


\begin{tabular}{|l|l|l|r|r|}
$\begin{array}{l}\text { Journal of } \\
\text { Endocrinology }\end{array}$ & T M Bohlen et al. & $\begin{array}{l}\text { Central GH action on sexual } \\
\text { maturation }\end{array}$ & $\mathbf{2 4 3 : 3}$ & $\mathbf{1 6 5}$ \\
\hline
\end{tabular}
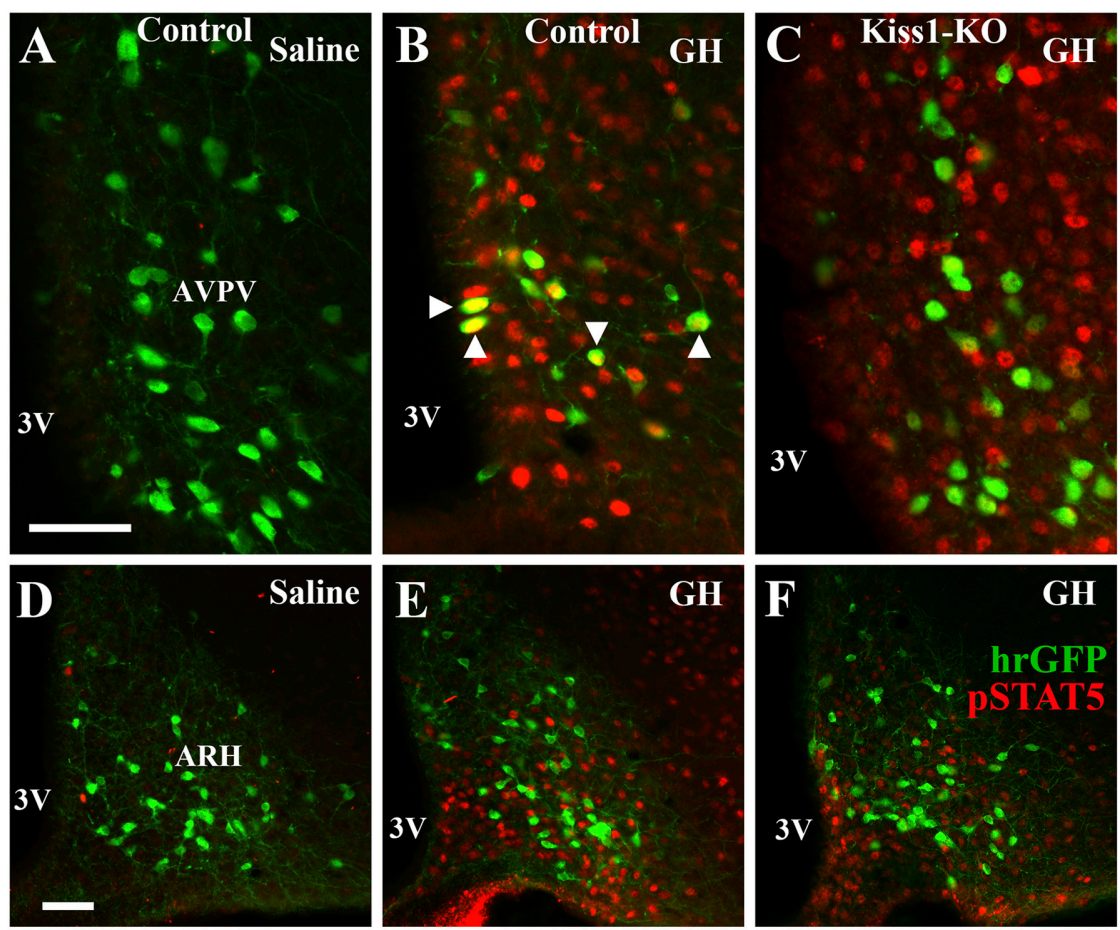

Figure 1

Validation of the Kiss1-KO model. Epifluorescence photomicrographs showing the distribution of the Kiss 1-Cre/GFP-positive cells (green cytoplasmic staining) in the anteroventral periventricular nucleus (AVPV, A, B, C) and in the arcuate nucleus $(A R H, D, E, F)$. Mice were treated with saline $(A, D)$ or porcine growth hormone ( $\mathrm{GH} ; \mathrm{B}, \mathrm{C}, \mathrm{E}, \mathrm{F})$. The GH-responsive cells were identified by PSTAT5positive staining (red nuclear staining). Doublelabeled cells appear as yellowish/orange (arrows; B). In the Kiss1-KO model the Kiss1-Cre/ GFP-positive cells in the AVPV did not express GH-induced PSTAT5 (C). 3V, third ventricle. Scale bar: $50 \mu \mathrm{m}$.
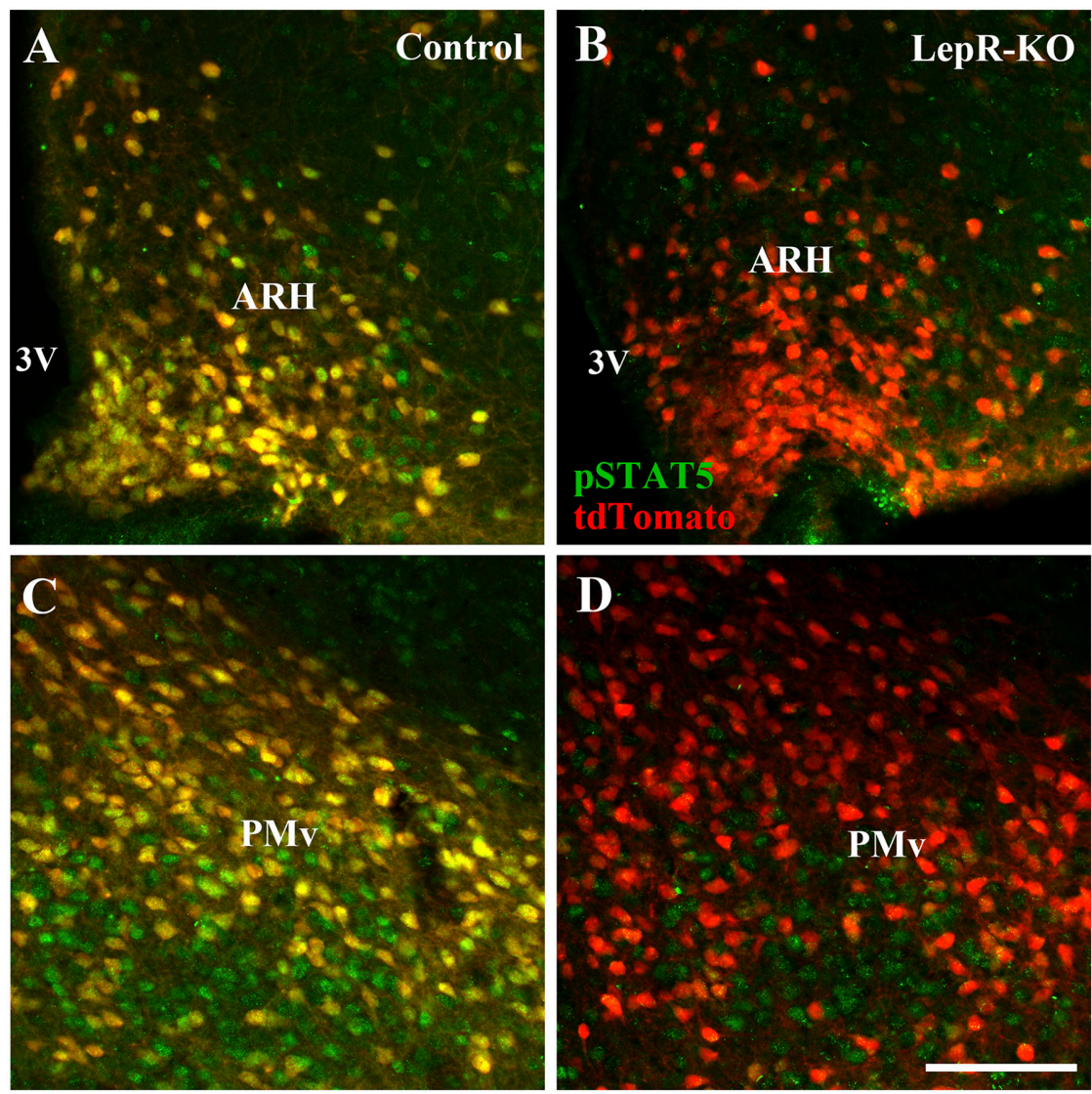

Figure 2

Validation of the LepR-KO model. (A, B and C) Epifluorescence photomicrograph showing the distribution of the leptin receptor (LepR) expressing cells (red cytoplasmic staining) in the arcuate $(A R H, A, B)$ and in the ventral premammillary nucleus (PMv, C, D). Control or the LepR-KO mice were treated with porcine growth hormone (GH). The GH-responsive cells were identified by the phosphorylation of STAT5 (pSTAT5)-positive staining (green nuclear). Double-labeled cells appear as yellowish/orange (arrows). 3V, third ventricle. Scale bar: $100 \mu \mathrm{m}$. 
Table 1 The Ghr mRNA levels in ovaries and perigonadal fat of female mice.

\begin{tabular}{l}
\hline Ghr mRNA \\
\hline Ovaries \\
Perigonadal fat \\
\hline
\end{tabular}

\begin{tabular}{c}
\hline Control $(n=5)$ \\
\hline $1.0 \pm 0.1 \mathrm{a} . \mathrm{u}$ \\
$1.0 \pm 0.2 \mathrm{a} . \mathrm{u}$ \\
\hline
\end{tabular}

\begin{tabular}{c}
\hline LepR-KO $(n=3)$ \\
\hline $1.5 \pm 0.3$ a.u \\
$1.3 \pm 0.1$ a.u \\
\hline
\end{tabular}

\begin{tabular}{c}
\hline Brain-KO $(n=5)$ \\
\hline $1.1 \pm 0.3$ a.u \\
$0.7 \pm 0.1$ a.u \\
\hline
\end{tabular}

\begin{tabular}{c}
\hline P value \\
\hline 0.7 \\
1.0 \\
\hline
\end{tabular}

which corresponded to the average age of first estrus (Silveira et al. 2017, Bohlen et al. 2018), were collected. The hypothalamic mRNA expression of neuropeptides and receptors involved in the regulation of reproductive axis and energy balance were assessed. Interestingly, when compared to control mice GHR ablation in kisspeptin cells significantly suppressed the hypothalamic expression of Gnrh1, Kiss1, Nos1 and Esr1 mRNA, but there were no detectable differences in the expression of Tac2, Gal, Esr2, Agrp, Npy, Pomc and Cartpt (Fig. 3A).

The hypothalamic mRNA levels were also evaluated in LepR-KO, Brain-KO and control mice. There was a significant reduction in Nos 1 expression in the Brain-KO mice, but no observable changes in Gnrh1, Kiss1, Tac2, Gal, Esr1 or Esr2 expression, when compared to control animals (Fig. 3B). With regards to the expression of genes related to energy balance regulation, the LepR-KO mice displayed reduced Agrp levels, but the extent of this decrease failed to reach significance $(P=0.1)$. In contrast, Agrp and Npy gene expression was significantly reduced in the hypothalami of Brain-KO mice, when compared to controls. No significant changes in Pomc or Cartpt mRNA expression in LepR-KO or Brain-KO mice were observed (Fig. 3B).

\section{Metabolic profile of Kiss1-KO, LepR-KO and Brain-KO mice}

The findings, up to this point, suggest that ablation of GH action in specific hypothalamic neurons may have genomic consequences in components of the HPG axis and neural circuits that regulate energy homeostasis. Therefore, the hormonal and metabolic profiles of the animals during puberty were recorded. In kisspeptin cells, GHR ablation was not able to induce significant alterations in body weight, body length, serum GH and leptin levels or uterine mass (Fig. 4). On the other hand, LepR-KO mice displayed reduced body weight at 42 days of age (Fig. 5A), despite the absence of changes in body length, when compared to control mice (Fig. 5B). Moreover, GHR ablation in LepR cells had no effect on GH secretion (Fig. 5C), but they showed reduced leptin levels, when compared to controls (Fig. 5D). Additionally, there were no observable differences in uterine mass
(Fig. 5E) of LepR-KO mice, when compared to control mice. With regards to Brain-KO mice, a significant increase in body length, as well, in serum GH levels were observed when compared to the control group (Fig. 5B and C). In addition, Brain-KO animals exhibited reduced serum leptin levels (Fig. 5D) and a non-significant increase in the uterine mass $(P=0.3)$ compared to control mice (Fig. 5E).

\section{Evaluation of sexual maturation in female Kiss1-KO mice}

To determine whether GH action on kisspeptin cells is required for puberty, we assessed the sexual maturation of Kiss1-KO and control mice by determining the age of the vaginal opening and first estrus. There were no differences detected for the occurrence of these events
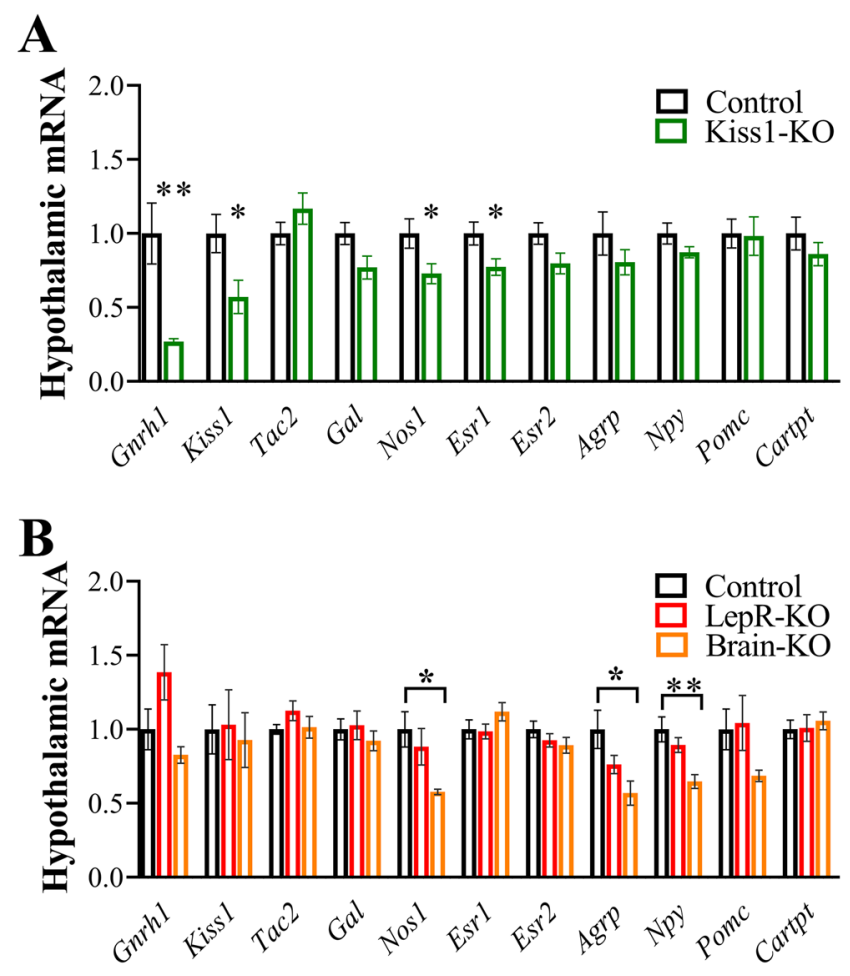

Figure 3

Hypothalamic mRNA expression analysis at 42 days of age. (A) Graphs comparing the mRNA expression between control and Kiss-KO mice $(n=7$ per group). (B) Graphs comparing the mRNA expression between control, LepR-KO and Brain-KO mice ( $n=8 / 6$ per group). ${ }^{*} p<0.005, * \star p<0.005$. A full colour version of this figure is available at https://doi.org/10.1530/ JOE-19-0242. 
A

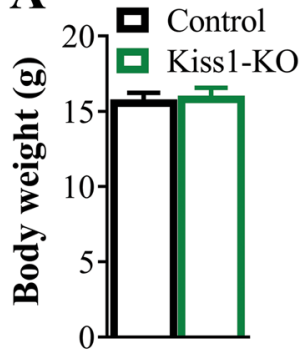

B

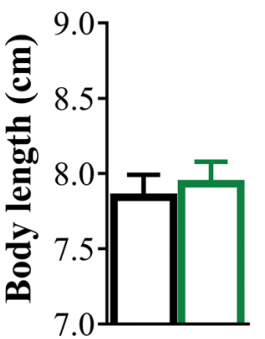

C

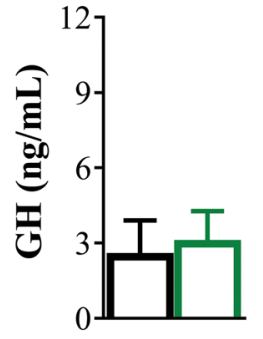

D

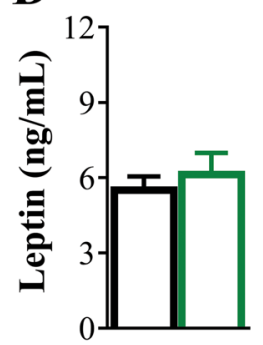

$\mathbf{E}$

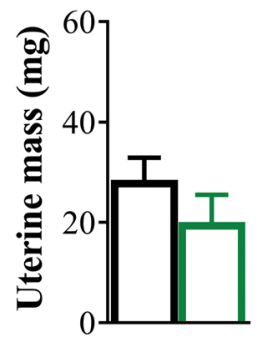

Figure 4

Metabolic and hormonal evaluation of control and Kiss1-KO mice at 42 days of age. (A, B, C, D, E and F) Graphs comparing body weight (A), body length (B), serum growth hormone $(\mathrm{GH})$ levels $(C)$, leptin levels $(D)$, estradiol levels (E) and the uterine mass (F) ( $n=6 / 12$ per group). $P>0.05$. A full colour version of this figure is available at https://doi.org/10.1530/ JOE-19-0242.

when comparing Kiss1-KO and control mice (Fig. 6A, B, $\mathrm{C}, \mathrm{D}$ and $\mathrm{E})$. In kisspeptin cells, GHR ablation also had no effect on body weight at specific sexual maturation stages or during development (Fig. 6C, F and G). Accordingly, the weight of the fad pads was similar between the groups (Fig. 6H). The estrous cycle patterns of Kiss1-KO and control mice were also evaluated and indicated that GH signaling in kisspeptin cells was not required for sex steroids mediation of the ovulatory cycle, since the two groups of mice exhibited similar estrous cycle lengths (Fig. 7).

\section{Evaluation of sexual maturation in female LepR-KO and Brain-KO mice}

Next, we determined whether ablation of GH signaling in LepR cells or in the brain disrupts and/or alters sexual maturation in these mice. It was found that the age of vaginal opening was not perturbed in LepR-KO or Brain-KO mice (Fig. 8A, B and C). However, the first estrus of the LepR-KO group was delayed, when compared to control mice (Fig. 8D and E). As shown in Fig. 8D, at 50 days of age $100 \%$ of control and $70 \%$ of Brain-KO mice had experienced their first cornification in the vaginal lavage, whereas fewer than $20 \%$ of LepR-KO mice had
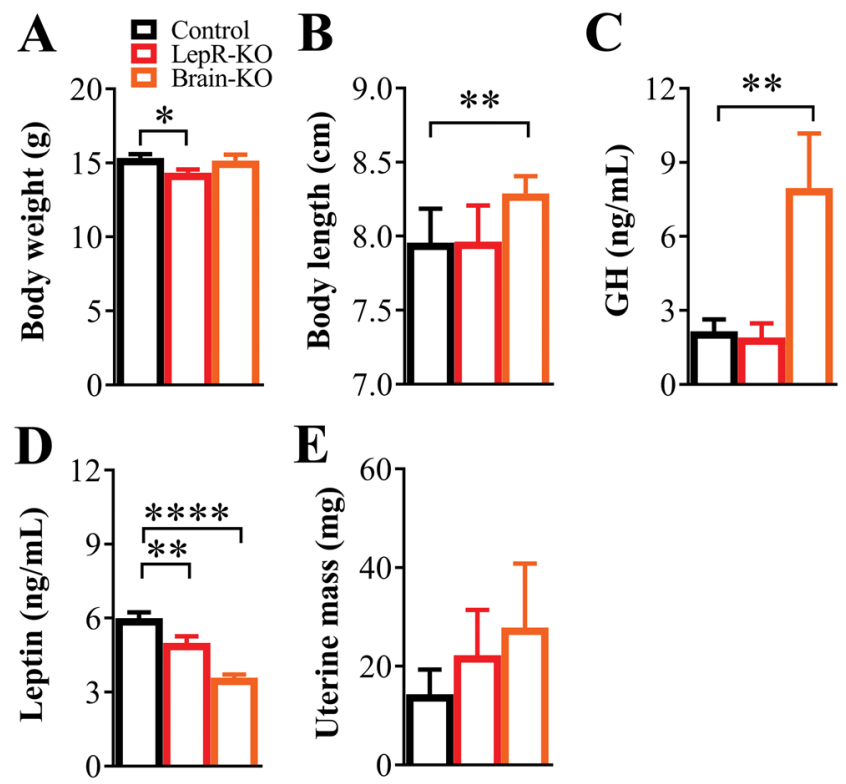

Figure 5

Metabolic and hormonal evaluation of control, LepR-KO and Brain-KO mice at 42 days of age. (A, B, C, D, E and F) Graphs comparing body weight $(A, n=18 / 23)$, body length $(B, n=9 / 12)$, serum growth hormone $(G H)$ levels (C), leptin levels ( $D, n=8 / 7$ per group) and the uterine mass (E) ( $n=6 / 10$ per group). ${ }^{\star} P<0.05 ; * \star P \leq 0.007, * \star \star \star x<0.0001$. A full colour version of this figure is available at https://doi.org/10.1530/JOE-19-0242.

reached that same stage of sexual maturation at that age $(P=0.02)$. However, there were no differences in the body weight on the days of vaginal opening or first estrus observed between groups. Interestingly, LepR-KO mice gained less weight during development, as demonstrated by the weekly body weight evaluation (Fig. 8G). This reduced weight gain was associated with lower fat pad mass (Fig. $8 \mathrm{H}$ ), lean mass (control: $14.1 \pm 0.3 \mathrm{~g}, n=12$; LepR-KO: $12.2 \pm 0.4 \mathrm{~g}, n=7 ; P=0.002)$ and whole body fat mass (control: $2.2 \pm 0.1 \mathrm{~g}, n=12$; LepR-KO: $1.7 \pm 0.1 \mathrm{~g}$, $n=7 ; P=0.001)$ in adult LepR-KO mice, when compared to control animals. On the other hand, brain GHR ablation induced no effect on sexual maturation or body weight gain (Fig. 8). Of note, adult Brain-KO female exhibited increased body length $(9.1 \pm 0.1 \mathrm{~cm}, n=11 ; P=0.004)$, and lean body mass $(15.5 \pm 0.2 \mathrm{~g}, n=12 ; P=0.001)$, despite no changes in whole body fat mass $(2.2 \pm 0.1 \mathrm{~g}, n=12 ; P=0.8)$, compared to control mice.

\section{Evaluation of the estrous cycle in female LepR-KO and Brain-KO mice}

Next the estrous cycles of adult mice were evaluated. We found that approximately $20 \%$ of LepR-KO mice (3 out of 16 animals) did not exhibit estrous cycles, whereas all 
A
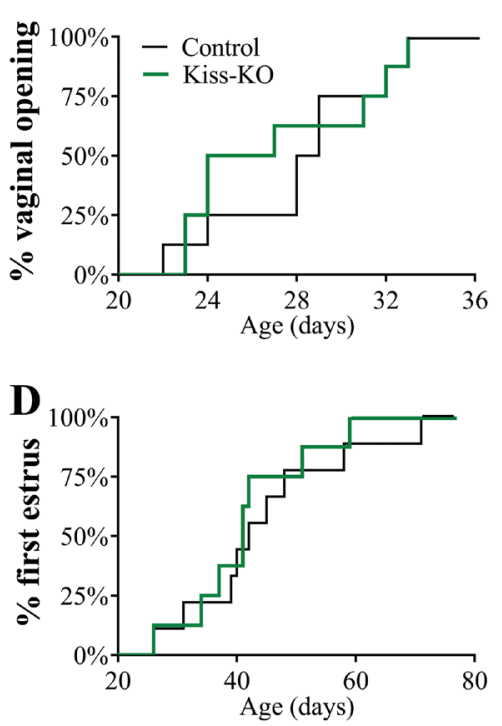

G

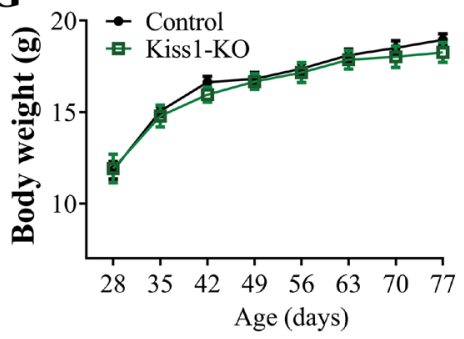

B

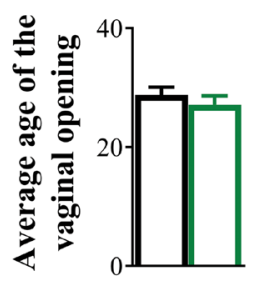

$\mathbf{E}$

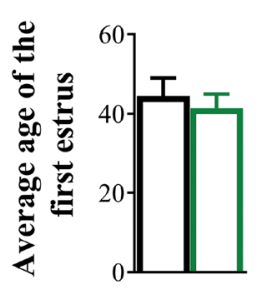

H

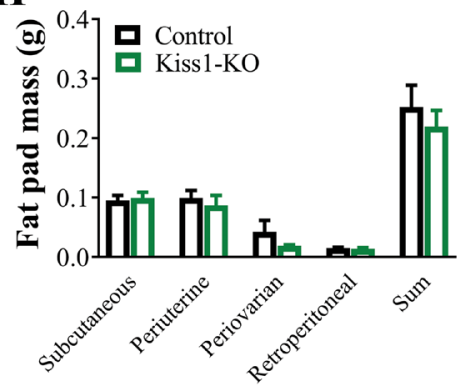

C
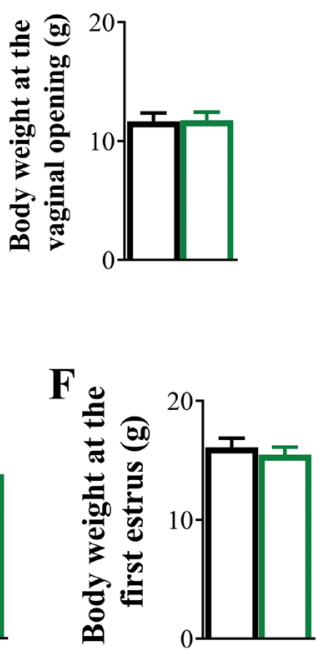

Figure 6

Growth hormone receptor (GHR) ablation from kisspeptin cells does not disrupt the sexual maturation. (A, D) Graphs showing the percentages of control and Kiss1-KO females that exhibited vaginal opening (A) and first estrus (D). $(B, E)$ Average time required for control and $\mathrm{KO}$ females to exhibit vaginal opening (B) and first estrus (E). (C, G) Body weight of control and $\mathrm{KO}$ mice at specific stages of sexual maturation (C, F) and throughout development (G). (H) Body adiposity was determined by measuring the weight of different adipose fat pads of adult female mice ( $n=9 / 8$ per group). $P>0.05$. A full colour version of this figure is available at https:// doi.org/10.1530/JOE-19-0242.
Brain-KO $(n=16)$ and control $(n=10)$ animals presented regular cycles. When compared to control mice, the remaining 13 LepR-KO animals displayed no significant differences in the percentage of days in which cornified cells or leucocytes were detected in the vaginal smear (Fig. 9A, B, C, D and E). In contrast, Brain-KO mice exhibited shorter estrous cycles (Fig. 9C and D), which were characterized by more days in which cornified cells were identified in the vaginal smear when compared to control mice (Fig. 9E). Additionally, the uterine mass of adult Brain-KO mice was increased, when compared to control animals (Fig. 9F).

\section{Discussion}

The present study provided evidence for the involvement of central GH-induced intracellular signaling in the sexual maturation of female mice. The results demonstrated that GH action in specific neural populations can potentially modulate the hypothalamic expression of genes related to the reproductive system or indirectly contribute to the progression of puberty. In addition, due to absence of GH signaling in LepR-expressing cells, the sex steroid mediated regulation of the ovulatory cycle may become compromised. Moreover, Brain-KO mice display shorter estrous cycles. Together, these results indicate that $\mathrm{GH}$ can modulate hypothalamic components of the HPG axis, although central GH signaling is not required for the timing of puberty in female mice.

The Kiss1-KO model revealed evidence for a significant reduction in the expression of genes related to the reproductive axis, including the Gnrh1, Kiss1, Nos1 and Esr1. Thus, suggesting that GH signaling in kisspeptin neurons is involved at some level, in the transcriptional regulation of these genes. Due to the fact that $\mathrm{GH}$ does not induce the phosphorylation of STAT5 or affect acute resting membrane potential responses in ARH kisspeptin cells (Silveira et al. 2019), the observed effects were likely mediated by the lack of GH action in AVPV/PeN neurons. However, it is unclear whether hypothalamic gene expression regulation is independent of $\mathrm{GH}$ action in kisspeptin ARH neurons, since GHR recruitment has been shown to activate the Src family kinase signaling pathway 

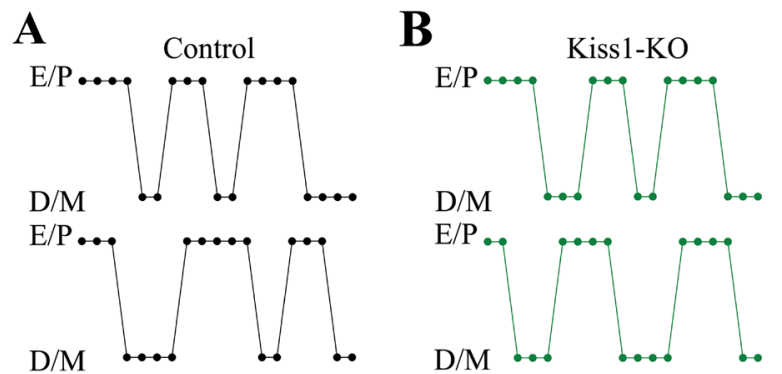

C

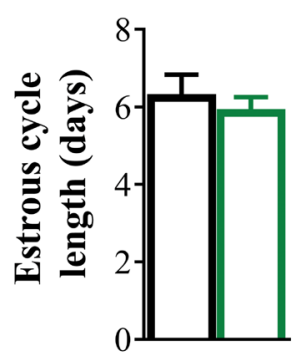

D

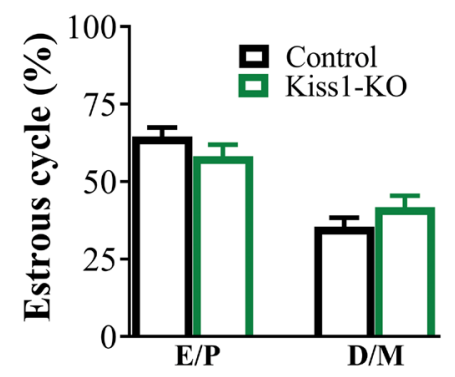

Figure 7

The growth hormone signaling in kisspeptin cells is not required for sex steroids mediation of the ovulatory cycle. Three consecutives estrous cycles were evaluated. The average length of the cycles (A, B and C) and the average percentage of days in which a predominance of cornified cells $(P / E)$ or leucocytes (D/M) were detected in the vaginal smear were determined (D) in control and Kiss1-KO mice ( $n=7$ per group). $P>0.05$. A full colour version of this figure is available at https://doi.org/10.1530/ JOE-19-0242.

in a JAK2-independent manner (Dehkhoda et al. 2018). Future studies should focus on the effects of GH on ARH kisspeptin neurons. It is plausible that these actions are initiated via the recruitment of other, not yet identified, signaling pathways or by circumstances that are known to affect reproduction, as well GH secretion, such as during fasting or in a malnourished state. Regardless of the specific mechanism, the observed differences in hypothalamic gene expression due to the ablation of GH signaling in kisspeptin cells seems to be cell type dependent, since GHR ablation in LepR cells had no effect on the hypothalamic levels of transcripts involved in the regulation of the reproductive axis, while a significant reduction of Nos1, Agrp and Npy expression was observed in Brain-KO mice.

Despite the significant reduction in the levels of essential genetic modulators of the HPG axis, it was concluded that GH action in kisspeptin cells was not required for sexual maturation or sex steroids mediation of the ovulatory cycle. This result was not particularly surprising, given that a previous study, which employed mice with $95 \%$ of the kisspeptin neurons ablated, showed that these animals still undergo normal sexual maturation,

exhibit a normal ovulatory cycle and are fertile (Mayer $\&$ Boehm 2011). Similarly, significant decreases in the number of the GnRH neurons or Gnrh1 expression had no impact on sexual maturation (Herbison et al. 2008). In this case, it is possible that Kiss1-KO mice undergo normal sexual maturation and are fertile because of the redundancy of the kisspeptin/GnRH system. On the other hand, lack of GH signaling in LepR cells was associated with lower body weight and reduced leptin serum levels. In accordance with the theory that a particular body fat content is necessary for sexual maturation (Frisch \& McArthur 1974, Frisch 1985), LepR-KO mice showed a significant delay in the time of the first estrus. In agreement with previous reports (Frisch \& McArthur 1974, Frisch 1985, Bohlen et al. 2016, 2018), LepR-KO mice had to first reach a certain body adiposity threshold before the first estrus. This indicates that GH signaling in LepR cells is involved in fat mass content regulation, which would indirectly influence the progression of puberty. Moreover, decreased energy stores throughout development could explain why some LepR-KO mice presented disrupted estrous cyclicity in adulthood. Additionally, we need to take into consideration that the ovaries and fat express Ghr, Kiss1 and LepR (Carlsson et al. 1993, Dupuis et al. 2014, Tu et al. 2015, Hu et al. 2017, Dudek et al. 2018). The direct GH action in the ovaries is necessary for normal follicular development and ovulation rate (Bachelot et al. 2002). Even though we demonstrated that Ghr mRNA expression was not affected in the ovaries or in the perigonadal fat, we cannot completely exclude the possibility that part of the observed effects resulted due to the lack of GH signaling in these tissues in the LepR-KO mice. In addition, whether GHR ablation in kisspeptinexpressing cells occurred in the ovaries in the Kiss1-KO model, it was not sufficient to modulated sex steroids mediation of the ovulatory cycle.

The brain GHR ablation failed to compromise the sexual maturation of female mice. Importantly, the NestinCre mice exhibit central expression of GH, which leads to reduction in pituitary GH secretion, secondary to the activation of negative feedback loops in the hypothalamus (Harno et al. 2013, Declercq et al. 2015). However, instead of reduced somatic growth, our Brain-KO mice show increased body weight, body length and circulating GH levels. The increased body growth of Brain-KO mice is likely caused by the absence of GH negative feedback in the hypothalamus leading to increased GHRH expression and high IGF-1 circulating levels, as shown previously (Furigo et al. 2019). Therefore, brain-specific GHR ablation prevents the neuroendocrine abnormalities exhibited 
A

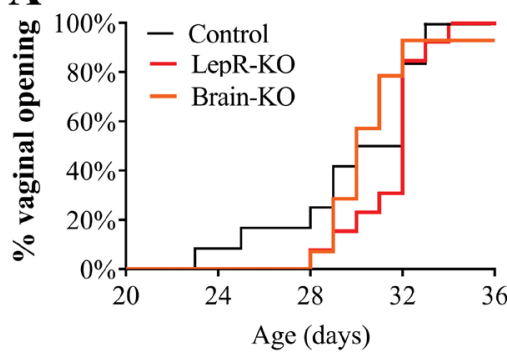

D

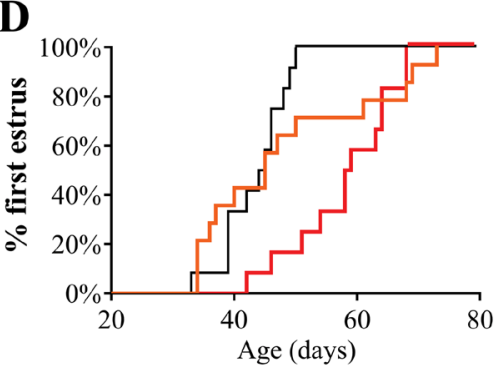

G

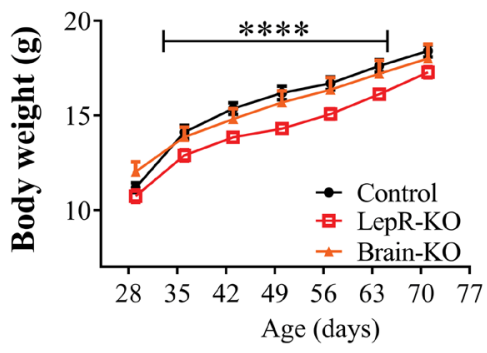

B

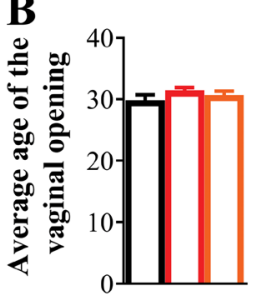

C

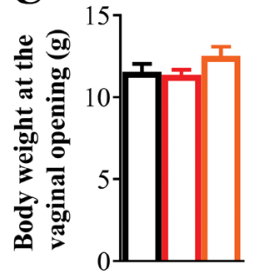

$\mathbf{E}$

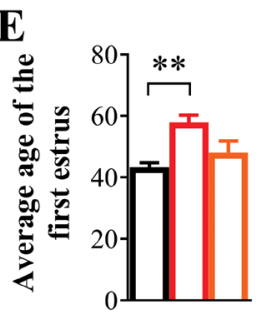

F

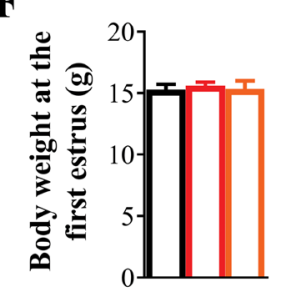

Figure 8

Evaluation of sexual maturation in female LepR-KO and Brain-KO mice. (A, D) Graphs showing the percentages of control, LepR-KO and Brain-KO females that exhibited vaginal opening (A) and first estrus (D). (B, E) Average time required for control and $\mathrm{KO}$ females to exhibit vaginal opening (B) and first estrus (E). (C, F, G) Body weight of control and $\mathrm{KO}$ mice at specific stages of sexual maturation (C, F) and throughout development $(\mathrm{G})$. (H) Body adiposity was determined by measuring the weight of different adipose fat pads of adult female mice. ( $n=9-14$ per group). $* * P \leq 0.004, * * * P=0.0003$,

$\star * \star * P \leq 0.001$. A full colour version of this figure is available at https://doi.org/10.1530/JOE-19-0242.

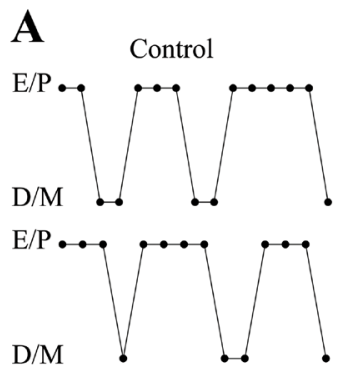

B

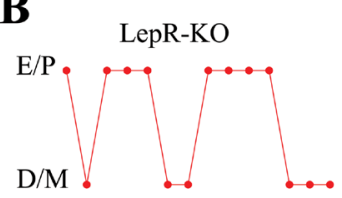

$\mathrm{E} / \mathrm{P}$
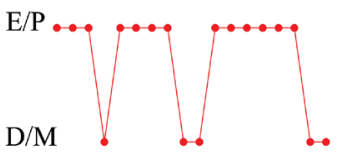

D

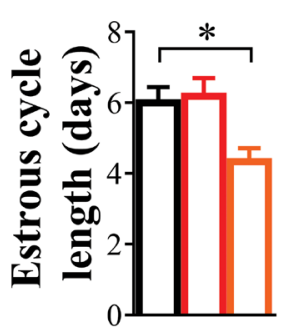

E

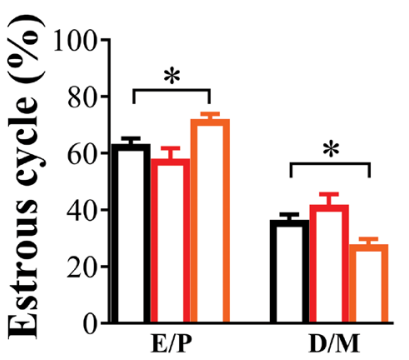

C

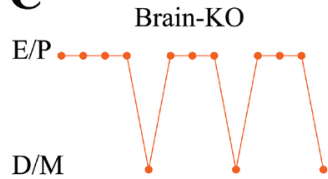

$\mathrm{E} / \mathrm{P}$

$\mathrm{D} / \mathrm{M}$

\section{$\mathbf{F}$}

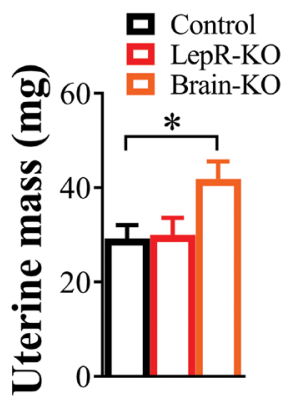

Figure 9

Evaluation of the estrous cycle in female LepR-KO and Brain-KO mice. Three consecutives estrous cycles were evaluated and the average length of a cycle (A, B, C and D) and the average percentage of days in which a predominance of cornified cells $(P / E)$ or leucocytes $(D / M)$ were detected in the vaginal smear were determined in control, LepR-KO and Brain-KO mice ( $\mathrm{E}, n=7 / 15$ per group). (F) Graph comparing the uterine mass of control, LepR-KO and Brain-KO mice ( $n=9 / 14$ per group). $* P<0.05$. A full colour version of this figure is available at https://doi.org/10.1530/ JOE-19-0242. 
by Nestin-Cre transgenic mice. Consider that Brain-KO female displayed increased uterine mass, increased $\mathrm{GH}$ and lower serum leptin levels, our results argue for whether the association of high circulating GH and serum estradiol levels can sufficiently and positively modulate the HPG axis and promote sexual maturation, even in the presence of low leptin levels. Furthermore, the lack of GH signaling in the brain resulted in shorter estrous cycles. In fact, even though gonadotropins are the main regulators of ovarian steroidogeneses, evidence suggests that GH can stimulate estradiol release (Doldi et al. 1996, Sirotkin 1996, Karamouti et al. 2008). Accordingly, in prepubertal female rats, chorionic gonadotropin-induced estradiol release is attenuated when GH release is suppressed (Advis et al. 1981). Therefore, increased GH serum levels may explain the increased uterine fat mass observed in adult Brain-KO females. However, it is unclear whether stimulatory $\mathrm{GH}$-induced estradiol secretion is able to modulate the ovulatory cycle in Brain-KO mice.

Nevertheless, it is important to highlight that IGF-1 is an important mediator of GH action (Powell-Braxton et al. 1993, Carroll et al. 1998). Indeed, IGF-1-deficient mice display reduced growth and metabolic disorders, among other dysfunctions (Powell-Braxton et al. 1993). However, the observed effects herein do not appear to be directly mediated by this growth factor, since there were no observable somatic effects. Furthermore, the administration of IGF-1, centrally or systemically, to prepubertal female rats augmented Kiss1 mRNA expression in the AVPV (Hiney et al. 2009), and animals harboring a conditional deletion of IGF-1 receptors in GnRH neurons exhibited delayed puberty onset (Divall et al. 2010). It is unknown whether IGF-1 directly modulates puberty, via signaling mechanisms in kisspeptin and LepR neurons. However, it is known that these neurons express the insulin receptor (IR) which could account for an indirect action of IGF-1 on the HPG axis (Qiu et al. 2013, Garcia-Galiano et al. 2017). Previous studies showed that disrupting insulin/IGF-1 signaling in kisspeptin or LepR cells, using an approach similar to the present study, resulted in significant delays of the first estrus, with no overt metabolic or reproductive phenotype in adults (Qiu et al. 2013, Garcia-Galiano et al. 2017). Further studies investigating the role of IGF-1 in LepR cells and the progression of puberty could yield some interesting conclusions.

In summary, previous studies (Cady et al. 2017, Furigo et al. 2019, Silveira et al. 2019), as well the present work, provide compelling evidence for the brain being a direct target of $\mathrm{GH}$ to regulate metabolic functions.
The consequences of inhibiting GH-induced intracellular signaling during development were primarily genomic, altering the gene expression levels of essential HPG axis components, as well as possible secondary metabolic changes. In most cases, sexual maturation appears to be uncompromised by the lack of GH action, an observation that is likely due to the redundancy of essential HPG axis modulators, resulting in satisfactory reproductive regulation and maintenance. Future studies seeking to evaluate the long-term effects of $\mathrm{GH}$ signaling in hypothalamic nuclei on reproduction need to be undertaken.

\section{Declaration of interest}

The authors declare that there is no conflict of interest that could be perceived as prejudicing the impartiality of the research reported.

\section{Funding}

This study was supported by the São Paulo Research Foundation (FAPESPBrazil, grant numbers: 2015/14588-5 (T M B), 2015/20198-5 (T T Z), 2016/09679-4 (I C F), 2017/02983-2 (J D) and 2017-21840-8 (R F)). J J K is supported, in part, by the State of Ohio's Eminent Scholar Program that includes a gift from Milton and Lawrence Goll and by NIH grant number AG059779 (J K, E O L).

\section{References}

Advis JP, White SS \& Ojeda SR 1981 Activation of growth hormone short loop negative feedback delays puberty in the female rat. Endocrinology 108 1343-1352. (https://doi.org/10.1210/endo-108-4-1343)

Albanese A \& Stanhope R 1994 Treatment of growth delay in boys with isolated growth hormone deficiency. European Journal of Endocrinology 130 65-69. (https://doi.org/10.1530/eje.0.1300065)

Bachelot A, Monget P, Imbert-Bolloré P, Coshigano K, Kopchick JJ, Kelly PA \& Binart N 2002 Growth hormone is required for ovarian follicular growth. Endocrinology 143 4104-4112. (https://doi. org/10.1210/en.2002-220087)

Bartke A 1964 Histology of the anterior hypophysis, thyroid and gonads of two types of dwarf mice. Anatomical Record 149 225-235.

Beltramino C \& Taleisnik S 1985 Ventral premammillary nuclei mediate pheromonal-induced LH release stimuli in the rat. Neuroendocrinology 41 119-124. (https://doi.org/10.1159/000124164)

Bohlen TM, Silveira MA, Zampieri TT, Frazao R \& Donato Jr J 2016 Fatness rather than leptin sensitivity determines the timing of puberty in female mice. Molecular and Cellular Endocrinology $\mathbf{4 2 3}$ 11-21. (https://doi.org/10.1016/j.mce.2015.12.022)

Bohlen TM, Silveira MA, Buonfiglio DDC, Ferreira-Neto HC, CipollaNeto J, Donato J \& Frazao R 2018 A short-day photoperiod delays the timing of puberty in female mice via changes in the kisspeptin system. Frontiers in Endocrinology 9 44. (https://doi.org/10.3389/ fendo.2018.00044)

Burton KA, Kabigting EB, Clifton DK \& Steiner RA 1992 Growth hormone receptor messenger ribonucleic acid distribution in the adult male rat brain and its colocalization in hypothalamic somatostatin neurons. Endocrinology 131 958-963. (https://doi.org/10.1210/ endo.131.2.1353444) (c) 2019 Society for Endocrinology Published by Bioscientifica Ltd. Printed in Great Britain 
Cady G, Landeryou T, Garratt M, Kopchick JJ, Qi N, Garcia-Galiano D, Elias CF, Myers MG, Miller RA, Sandoval DA, et al. 2017 Hypothalamic growth hormone receptor (GHR) controls hepatic glucose production in nutrient-sensing leptin receptor (LepRb) expressing neurons. Molecular Metabolism 6 393-405. (https://doi.org/10.1016/j. molmet.2017.03.001)

Carlsson B, Nilsson A, Isaksson OGP \& Billig H 1993 Growth hormonereceptor messenger RNA in the rat ovary: regulation and localization. Molecular and Cellular Endocrinology 95 59-66. (https://doi. org/10.1016/0303-7207(93)90029-j)

Carroll PV, Christ ER, Bengtsson BA, Carlsson L, Christiansen JS, Clemmons D, Hintz R, Ho K, Laron Z, Sizonenko P, et al. 1998 Growth hormone deficiency in adulthood and the effects of growth hormone replacement: a review. Growth Hormone Research Society Scientific Committee. Journal of Clinical Endocrinology and Metabolism 83 382-395. (https://doi.org/10.1210/jcem.83.2.4594)

De Boer JAM, Schoemaker J \& Van Der Veen EA 1997 Impaired reproductive function in women treated for growth hormone deficiency during childhood. Clinical Endocrinology 46 681-689. (https://doi.org/10.1046/j.1365-2265.1997.1800999.x)

Declercq J, Brouwers B, Pruniau VP, Stijnen P, de Faudeur G, Tuand K, Meulemans S, Serneels L, Schraenen A, Schuit F, et al. 2015 Metabolic and behavioural phenotypes in nestin-Cre mice are caused by hypothalamic expression of human growth hormone. PLOS ONE $\mathbf{1 0}$ e0135502. (https://doi.org/10.1371/journal.pone.0135502)

Dehkhoda F, Lee CMM, Medina J \& Brooks AJ 2018 The growth hormone receptor: mechanism of receptor activation, cell signaling, and physiological aspects. Frontiers in Endocrinology 9 35. (https://doi. org/10.3389/fendo.2018.00035)

Devesa J, Lima L \& Tresguerres JAF 1992 Neuroendocrine control of growth hormone secretion in humans. Trends in Endocrinology and Metabolism 3 175-183. (https://doi.org/10.1016/10432760(92)90168-Z)

Devesa J, Almenglo C \& Devesa P 2016 Multiple effects of growth hormone in the body: is it really the hormone for growth? Clinical Medicine Insights: Endocrinology and Diabetes 9 47-71. (https://doi. org/10.4137/CMED.S38201)

Divall SA, Williams TR, Carver SE, Koch L, Brüning JC, Kahn CR, Wondisford F, Radovick S \& Wolfe A 2010 Divergent roles of growth factors in the GnRH regulation of puberty in mice. Journal of Clinical Investigation 120 2900-2909. (https://doi.org/10.1172/JCI41069)

Doldi N, Bassan M, Bonzi V \& Ferrari A 1996 Effects of growth hormone and growth hormone-releasing hormone on steroid synthesis in cultured human luteinizing granulosa cells. Gynecological Endocrinology 10 101-108. (https://doi.org/10.3109/09513599609097899)

Donato Jr J \& Elias CF 2011 The ventral premammillary nucleus links metabolic cues and reproduction. Frontiers in Endocrinology 257. (https://doi.org/10.3389/fendo.2011.00057)

Donato Jr J, Silva RJ, Sita LV, Lee S, Lee C, Lacchini S, Bittencourt JC, Franci CR, Canteras NS \& Elias CF 2009 The ventral premammillary nucleus links fasting-induced changes in leptin levels and coordinated luteinizing hormone secretion. Journal of Neuroscience $\mathbf{2 9}$ 5240-5250. (https://doi.org/10.1523/JNEUROSCI.0405-09.2009)

Donato Jr J, Cavalcante JC, Silva RJ, Teixeira AS, Bittencourt JC \& Elias CF 2010 Male and female odors induce Fos expression in chemically defined neuronal population. Physiology and Behavior 99 67-77. (https://doi.org/10.1016/j.physbeh.2009.10.012)

Donato Jr J, Lee C, Ratra DV, Franci CR, Canteras NS \& Elias CF 2013 Lesions of the ventral premammillary nucleus disrupt the dynamic changes in Kiss1 and GnRH expression characteristic of the proestrusestrus transition. Neuroscience 241 67-79. (https://doi.org/10.1016/j. neuroscience.2013.03.013)

Dudek M, Ziarniak K \& Sliwowska JH 2018 Kisspeptin and metabolism: the brain and beyond. Frontiers in Endocrinology 9 145-145. (https:// doi.org/10.3389/fendo.2018.00145)
Dupuis L, Schuermann Y, Cohen T, Siddappa D, Kalaiselvanraja A, Pansera M, Bordignon V \& Duggavathi R 2014 Role of leptin receptors in granulosa cells during ovulation. Reproduction 147 221-229. (https://doi.org/10.1530/REP-13-0356)

Eden S 1979 Age-related and sex-related differences in episodic growthhormone secretion in the rat. Endocrinology 105 555-560. (https://doi. org/10.1210/endo-105-2-555)

Frisch RE 1985 Fatness, menarche, and female fertility. Perspectives in Biology and Medicine 28 611-633. (https://doi.org/10.1353/ pbm.1985.0010)

Frisch RE \& McArthur JW 1974 Menstrual cycles: fatness as a determinant of minimum weight for height necessary for their maintenance or onset. Science 185 949-951. (https://doi.org/10.1126/ science.185.4155.949)

Furigo IC, Metzger M, Teixeira PD, Soares CR \& Donato Jr J 2017 Distribution of growth hormone-responsive cells in the mouse brain. Brain Structure and Function 222 341-363. (https://doi.org/10.1007/ s00429-016-1221-1)

Furigo IC, Teixeira PDS, de Souza GO, Couto GCL, Romero GG, Perelló M, Frazão R, Elias LL, Metzger M, List EO, et al. 2019 Growth hormone regulates neuroendocrine responses to weight loss via AgRP neurons. Nature Communications 10 662. (https://doi.org/10.1038/s41467-01908607-1)

Garcia-Galiano D, Borges BC, Donato Jr J, Allen SJ, Bellefontaine N, Wang M, Zhao JJ, Kozloff KM, Hill JW \& Elias CF 2017 PI3Kalpha inactivation in leptin receptor cells increases leptin sensitivity but disrupts growth and reproduction. JCI Insight 2 e96728. (https://doi. org/10.1172/jci.insight.96728)

Giampietro A, Milardi D, Bianchi A, Fusco A, Cimino V, Valle D, Marana R, Pontecorvi A \& De Marinis L 2009 The effect of treatment with growth hormone on fertility outcome in eugonadal women with growth hormone deficiency: report of four cases and review of the literature. Fertility and Sterility 91 930.e7-930.11. (https://doi. org/10.1016/j.fertnstert.2008.09.065)

Harno E, Cottrell EC \& White A 2013 Metabolic pitfalls of CNS Cre-based technology. Cell Metabolism 18 21-28. (https://doi.org/10.1016/j. cmet.2013.05.019)

Herbison AE, Porteous R, Pape JR, Mora JM \& Hurst PR 2008 Gonadotropin-releasing hormone neuron requirements for puberty, ovulation, and fertility. Endocrinology 149 597-604. (https://doi. org/10.1210/en.2007-1139)

Hiney JK, Srivastava VK, Pine MD \& Les Dees W 2009 Insulin-like growth factor-I activates KiSS-1 gene expression in the brain of the prepubertal female rat. Endocrinology 150 376-384. (https://doi. org/10.1210/en.2008-0954)

Hu KL, Zhao H, Chang HM, Yu Y \& Qiao J 2017 Kisspeptin/kisspeptin receptor system in the ovary. Frontiers in Endocrinology 8 365-365. (https://doi.org/10.3389/fendo.2017.00365)

Karamouti M, Kollia P, Kallitsaris A, Vamvakopoulos N, Kollios G \& Messinis IE 2008 Growth hormone, insulin-like growth factor I, and leptin interaction in human cultured lutein granulosa cells steroidogenesis. Fertility and Sterility 90 1444-1450. (https://doi. org/10.1016/j.fertnstert.2007.08.076)

Leshan RL \& Pfaff DW 2014 The hypothalamic ventral premammillary nucleus: a key site in leptin's regulation of reproduction. Journal of Chemical Neuroanatomy 61-62 239-247. (https://doi.org/10.1016/j. jchemneu.2014.08.008)

Lehman MN, Coolen LM, Steiner RA, Neal-Perry G, Wang L, Moenter SM, Moore AM, Goodman RL, Yeo SH, Padilla SL, et al. 2018 The 3rd World Conference on Kisspeptin, 'Kisspeptin 2017: Brain and Beyond': unresolved questions, challenges and future directions for the field. Journal of Neuroendocrinology $\mathbf{3 0} \mathrm{e} 12600$.

List EO, Berryman DE, Funk K, Gosney ES, Jara A, Kelder B, Wang X, Kutz L, Troike K, Lozier N, et al. 2013 The role of GH in adipose tissue: lessons from adipose-specific GH receptor gene-disrupted https://joe.bioscientifica.com https://doi.org/10.1530/JOE-19-0242 (c) 2019 Society for Endocrinology Published by Bioscientifica Ltd. Printed in Great Britain 
mice. Molecular Endocrinology 27 524-535. (https://doi.org/10.1210/ me.2012-1330)

List EO, Berryman DE, Funk K, Jara A, Kelder B, Wang F, Stout MB, Zhi X, Sun L, White TA, et al. 2014 Liver-specific GH receptor gene-disrupted (LiGHRKO) mice have decreased endocrine IGF-I, increased local IGFI, and altered body size, body composition, and adipokine profiles. Endocrinology 155 1793-1805. (https://doi.org/10.1210/en.2013-2086)

Lomniczi A, Loche A, Castellano JM, Ronnekleiv OK, Bosch M, Kaidar G, Knoll JG, Wright H, Pfeifer GP \& Ojeda SR 2013 Epigenetic control of female puberty. Nature Neuroscience 16 281-289. (https://doi. org/10.1038/nn.3319)

Manfredi-Lozano M, Roa J, Ruiz-Pino F, Piet R, Garcia-Galiano D, Pineda R, Zamora A, Leon S, Sanchez-Garrido MA, Romero-Ruiz A, et al. 2016 Defining a novel leptin-melanocortin-kisspeptin pathway involved in the metabolic control of puberty. Molecular Metabolism 5 844-857. (https://doi.org/10.1016/j.molmet.2016.08.003)

Mayer C \& Boehm U 2011 Female reproductive maturation in the absence of kisspeptin/GPR54 signaling. Nature Neuroscience $\mathbf{1 4}$ 704-710. (https://doi.org/10.1038/nn.2818)

Nelson JF, Karelus K, Felicio LS \& Johnson TE 1990 Genetic influences on the timing of puberty in mice. Biology of Reproduction 42 649-655. (https://doi.org/10.1095/biolreprod42.4.649)

Padilla SL, Qiu J, Nestor CC, Zhang C, Smith AW, Whiddon BB, Ronnekleiv OK, Kelly MJ \& Palmiter RD 2017 AgRP to Kiss1 neuron signaling links nutritional state and fertility. PNAS 114 2413-2418. (https://doi.org/10.1073/pnas.1621065114)

Powell-Braxton L, Hollingshead P, Warburton C, Dowd M, Pitts-Meek S, Dalton D, Gillett N \& Stewart TA 1993 IGF-I is required for normal embryonic growth in mice. Genes and Development 7 2609-2617. (https://doi.org/10.1101/gad.7.12b.2609)

Qiu X, Dowling AR, Marino JS, Faulkner LD, Bryant B, Brüning JC, Elias CF \& Hill JW 2013 Delayed puberty but normal fertility in mice with selective deletion of insulin receptors from kiss1 cells. Endocrinology 154 1337-1348. (https://doi.org/10.1210/en.2012-2056)

Ross RA, Leon S, Madara JC, Schafer D, Fergani C, Maguire CA, Verstegen AMJ, Brengle E, Kong D, Herbison AE, et al. 2018 PACAP neurons in the ventral premammillary nucleus regulate reproductive function in the female mouse. elife 7 e35960. (https://doi. org/10.7554/eLife.35960)
Silveira MA, Furigo IC, Zampieri TT, Bohlen TM, de Paula DG, Franci CR, Donato Jr J \& Frazao R 2017 STAT5 signaling in kisspeptin cells regulates the timing of puberty. Molecular and Cellular Endocrinology 448 55-65. (https://doi.org/10.1016/j.mce.2017.03.024)

Silveira MA, Zampieri TT, Furigo IC, Abdulkader F, Donato Jr J \& Frazao R 2019 Acute effects of somatomammotropin hormones on neuronal components of the hypothalamic-pituitary-gonadal axis. Brain Research 1714 210-217. (https://doi.org/10.1016/j. brainres.2019.03.003)

Sirotkin AV 1996 Direct action of growth hormone on bovine ovarian cells: effects on estradiol, oxytocin, vasopressin release by granulosa cells and on oocyte maturation and cleavage in vitro. Annales d'Endocrinologie 57 219-224.

Smuel K, Kauli R, Lilos P \& Laron Z 2015 Growth, development, puberty and adult height before and during treatment in children with congenital isolated growth hormone deficiency. Growth Hormone and IGF Research 25 182-188. (https://doi.org/10.1016/j. ghir.2015.05.001)

Souza FM \& Collett-Solberg PF 2011 Adverse effects of growth hormone replacement therapy in children. Arquivos Brasileiros de Endocrinologia e Metabologia 55 559-565. (https://doi.org/10.1590/S000427302011000800009)

Steyn FJ, Tolle V, Chen C \& Epelbaum J 2016 Neuroendocrine regulation of growth hormone secretion. Comprehensive Physiology 6 687-735. (https://doi.org/10.1002/cphy.c150002)

Tu X, Kuang Z, Gong X, Shi Y, Yu L, Shi H, Wang J \& Sun Z 2015 The influence of LepR tyrosine site mutations on mouse ovary development and related gene expression changes. PLOS ONE 10 e0141800. (https://doi.org/10.1371/journal.pone.0141800)

Walsh RJ, Mangurian LP \& Posner BI 1990 The distribution of lactogen receptors in the mammalian hypothalamus: an in vitro autoradiographic analysis of the rabbit and rat. Brain Research $\mathbf{5 3 0}$ 1-11. (https://doi.org/10.1016/0006-8993(90)90651-q)

Zhou Y, Xu BC, Maheshwari HG, He L, Reed M, Lozykowski M, Okada S, Cataldo L, Coschigamo K, Wagner TE, et al. 1997 A mammalian model for Laron syndrome produced by targeted disruption of the mouse growth hormone receptor/binding protein gene (the Laron mouse). PNAS 94 13215-13220. (https://doi.org/10.1073/ pnas.94.24.13215)

Received in final form 6 August 2019

Accepted 30 August 2019

Accepted Preprint published online 30 August 2019 